\title{
HOME LEARNING ENVIRONMENT AND COGNITIVE DEVELOPMENT DURING EARLY CHILDHOOD EDUCATION
}

\author{
Mariane Campelo Koslinski ${ }^{1}$ \\ Renata Corrêa Gomes² \\ Blenda Luize Chor Rodrigues ${ }^{3}$ \\ Felipe Macedo de Andrade 4 \\ Tiago Lisboa Bartholo 5
}

\begin{abstract}
The paper explores the Home Learning Environment concept's potential to enhance understanding of educational inequalities at the beginning of compulsory schooling in Brazil. The data comes from a longitudinal study conducted from 2017 to 2018 in a random sample of 46 schools and approximately 2,700 children attending preschool in a public municipal system. The linear and multilevel regression models indicate that the Home Learning Environment measure is associated with cognitive development at the beginning of compulsory schooling (effect sizes from 0.229 to 0.308 ) and learning during preschool (effect sizes from 0.123 to 0.152 ). It discusses the relevance of the findings for policies to support families and project possible effects of the pandemic on educational inequalities.
\end{abstract}

Keywords: Home Learning Environment. Early childhood education. Longitudinal study. Socio-educational inequality.

\section{AMBIENTE DE APRENDIZAGEM EM CASA E O DESENVOLVIMENTO COGNITIVO NA EDUCAÇÃO INFANTIL}

RESUMO: $\mathrm{O}$ artigo explora o potencial do conceito de Ambiente de Aprendizagem em Casa para compreender desigualdades educacionais no início da escolarização obrigatória no Brasil. Utiliza dados de um estudo longitudinal realizado entre 2017 e 2018 em uma amostra aleatória de 46 escolas e 2.716 crianças matriculadas

\footnotetext{
The longitudinal study that resulted in this article was financed by the Inter-Banco Interamericano de Desenvolvimento, Fundação Carlos Chagas Filho de Amparo à Pesquisa do Estado do Rio de Janeiro, Conselho Nacional de Desenvolvimento Científico e Tecnológico and Instituto Alfa e Beto.

1.Universidade Federal do Rio de Janeiro - Centro de Filosofia e Ciências Humanas -Faculdade de Educação - Rio de Janeiro (RJ), Brazil. E-mail: mckoslinski@ufrj.com

2.Stanford University - Graduate School of Education - International Education Policy Analysis - Stanford (CA), United States of America.E-mail: renatacgomes95@gmail.com

3.University of North Carolina at Greensboro - School of Health and Human Sciences - Human Development and Family Studies - Greensboro (NC), United States of America. E-mail: bcrodri2@uncg.edu

4.Universidade Federal do Rio de Janeiro - Centro de Filosofia e Ciências Humanas - Colégio de Aplicação - Rio de Janeiro (RJ), Brazil. E-mail: felipema8@gmail.com

5.Universidade Federal do Rio de Janeiro - Centro de Filosofia e Ciências Humanas - Colégio de Aplicação - Rio de Janeiro (RJ), Brazil. E-mail: tiagobartholo@ufrj.com

Section Editor: Luana Costa Almeida
} 
na pré-escola de uma rede pública municipal. Os modelos de regressão linear e multinível estimados indicaram uma associação entre a medida de Ambiente de Aprendizagem em Casa e o desenvolvimento cognitivo no início da escolarização obrigatória (effect sizes de 0,229 a 0,308 ), bem como a aprendizagem das crianças durante a pré-escola (effect sizes de 0,123 a 0,152). Discute-se a relevância dos resultados para subsidiar políticas de apoio às famílias e projetar possíveis efeitos da pandemia nas desigualdades educacionais.

Palavras-chave: Ambiente de Aprendizagem em Casa. Educação infantil. Estudo longitudinal. Desigualdades socioeducacionais.

\section{AMBIENTE DE APRENDIZAJE EN EL HOGAR Y DESAROLLO COGNITIVO EN EDUCACIÓN INFANTIL}

RESUMEN: El artículo explora el potencial del concepto de Ambiente de Aprendizaje em el Hogar para comprender las desigualdades educativas al inicio de la escolaridad obligatoria en Brasil. Utiliza datos de un estudio longitudinal realizado entre 2017 y 2018 em una muestra aleatoria de 46 escuelas y 2.716 niños matriculados em el preescolar de una red municipal pública. Los modelos de regresión linear y multinivel estimados indicaron una asociación entre la medición de Ambiente de Aprendizaje en el Hogar y el desarrollo cognitivo al comienzo de la escolaridad obligatoria (effect sizes de 0,229 a 0,308), así como el aprendizaje de los niños durante el preescolar (effect sizes de 0,123 a 0,152). Se discute la relevancia de los resultados para informar las políticas apoyo familiar y proyectar los posibles efectos de la pandemia sobre las desigualdades educativas.

Palabras-clave: Ambiente de Aprendizaje em el Hogar. Educación infantil. Estudio longitudinal. Desigualdades socioeducativas.

\section{Introduction}

$\mathrm{T}$

he relationship between students' socioeconomic status (SES) and school success is widely studied in the sociology of education. For example, the Coleman report, from 1966, already observed that the intra-school variation was greater than the variation between schools, which indicated a greater weight of social origin in student performance than the school factors considered in the study. Subsequently, studies on school effectiveness - based on research with longitudinal designs and more accurate measures of students' SES -, even identifying a greater effect of schools also observed a strong association between social origin and student learning (BROOKE; SOARES, 2008). Even though it is a universal phenomenon, studies indicate that the strength of the relationship between SES and school success varies greatly between countries/education systems and over time. (CRAHAY; BAYE, 2013; SIRIN, 2005).

The relationship between the SES of students and other important social background characteristics and school performance/track record was also the focus of several studies developed in the Brazilian context. (BONAMINO et al., 2010; FRANCO et al., 2007; SOARES, 2004).However, most of these studies use large-scale assessment systems with cross-sectional designs and, therefore, do not adequately estimate the impact of such variables on student learning. Even those that use longitudinal data, such as the Longitudinal Study of the School Generation 2005 survey or studies that use external 
assessment systems with a longitudinal design, only have baseline measurements referring to the beginning of the 1st grade/2nd year ( BROOKE; BONAMINO, 2011) or at the end of the 1st, 2nd or 3rd years of Elementary School (SOARES et al., 2017; CASTRO, 2016), which brings us to the second gap in Brazilian studies: the almost total lack of information about inequalities or the effect of family origin on children's cognitive development at the beginning of the current compulsory schooling. In Brazil, despite the recent expansion of access to early childhood education - and the expansion of compulsory education for children aged 4 and 5, this level of education still remains far removed from discussions on educational inequalities (RODRIGUES; MUANIS, 2020; KOSLINSKI; BARTHOLO, 2019, 2020).

Finally, longitudinal studies, mainly developed in the USA and the United Kingdom, investigating children who attend preschool and/or at the beginning of compulsory education, observed, in the development of these children, inequalities related not only to SES but also to internal processes of families; that is, learning opportunities that adults provide for children in the family context (SYLVA et al., 2010; SAMMONS et al., 2008; RODRIGUEZ; TAMIS-LEMONDA, 2011). Again, few studies in Brazil observe the association of variables of family interactions with children's development, and even existing studies have restrictions because they include few cases and/or do not present longitudinal designs (ANDRADE et al., 2005; CACHAPUZ; HALPERN, 2006; FERREIRA; BARRERA, 2010).

Given these gaps, this article starts from a bibliography on the concept of Home Learning Environment (HLE), translated in Portuguese as Ambiente de Aprendizagem em Casa (AAC), and explores its potential to understand inequalities in children's development at the beginning of compulsory education in the Brazilian context. To do so, it uses data from a longitudinal study carried out between 2017 and 2018, which comprised a random sample of 46 schools and 2,716 children aged 4 to 5 years who attended municipal public education in a Brazilian capital.

The article is divided into four parts, and this introduction and final considerations to achieve the proposed objective. The first part discusses the concept of HLE and the evidence found in large-scale studies about its relationship with the learning of children in preschool and/or at the beginning of compulsory schooling. Then, studies carried out in the Brazilian context that focus on similar concepts and seek to associate them with school success are discussed. The second part discusses the design of the longitudinal study that served as the basis for the analysis carried out in this article. The study involves three waves of data collection on cognitive development of children during the two years of compulsory schooling, using an adaptation for the Brazilian context of the instrument Performance Indicators in Primary Schools (PIPS) (BARTHOLO et al., 2020a), in addition to the questionnaire application for parents/guardians.

The third part of the article presents the HLE indicator drawn up from items in these questionnaires. The fourth part presents bivariate and multivariate analysis that use the HLE indicator as an explanatory variable in linear regressions, which estimate the cognitive development of children at the beginning of compulsory schooling and in multilevel regressions, with value-added models that, in turn, estimate the learning of children during the two years of preschool. In its final considerations, the article defends the importance of carrying out large-scale longitudinal studies and looking at the relationship between HLE and the development of children in early childhood education. It is argued that in-depth studies of this relationship can generate important evidence to inform public policies focusing on interactions between children and families and on the family-school relationship. Furthermore, in the context of a pandemic, these studies can contribute to the understanding of mechanisms through which schools' closure and social distancing measures can widen up educational inequalities. 


\section{Home Learning Environment and Association with Children's Development}

In Brazil, the 1988 Constitution was the first legal document to guarantee the right of children aged 0 to 6 years to be cared for in daycare centers and preschools. From the Law of Guidelines and Bases of Education (1996), early childhood education came to be defined as the first stage of basic education. In 2009, Constitutional Amendment n. 59 extended compulsory and free education from 4 to 17 years of age and indicated that the universalization of this service should be progressively completed by 2016. Thus, there are extensive efforts to expand early childhood education throughout the national territory, resulting in children starting their education trajectory earlier and earlier. Still, for most Brazilian children, the school trajectory begins at age 4, since, even with the expansion of vacancies, in 2019, only $37 \%$ of children aged 0 to 3 attended daycare (OPNE, nd).

Despite this change, the segment remains far from discussing inequalities in education (RODRIGUES; MUANIS, 2020). This absence is understandable, in part, because, in the Brazilian context, we have few longitudinal studies ${ }^{1}$ and/or more robust designs to explore relationships between social inequalities and learning, whether at the beginning of compulsory education or during the school trajectory of elementary and high school students. Such scarcity is observed in early childhood education, with the aggravation of the compulsory schooling of children aged 4 to 5 is very recent (KOSLINSKI; BARTHOLO, 2020).

In conjunction with the debate on educational inequalities in early childhood education, studies have observed that, in early childhood, the family, as children's most immediate context, exerts a significant influence on what they learn and their starting points. In this context, children have their first experiences of socialization and learning, which can, in turn, be expanded and enhanced by the action of adults who live with them. In this sense, recent studies carried out in different contexts/education systems in order to understand school and extra-school factors that influence the development and school trajectory of young children, in addition to issues related to their socioeconomic origin, have developed and have used the concept of Home Learning Environment (HLE) or Ambiente de Aprendizagem em Casa (AAC). This concept reflects the learning opportunities that adults provide for children in the family context and is generally measured through active engagement in learning activities with children, such as: reading books, playing with numbers, painting and drawing, teaching songs/poems/rhymes etc. (TAGGART et al., 2011; SYLVA et al., 2010; SAMMONS et al., 2008).

The HLE refers to the experience of children living in the context of their family and community, based on the bioecological model of development (BRONFENBRENNER; MORRIS, 2006). This model discusses how environments such as the family, school and community, as well as the processes experienced by children associated with their characteristics, relate to and influence their development over time. From this perspective, in the first years of life, the family exerts the most significant influence on the development of children, as this is the most immediate context with which it interacts.

The HLE indicator, in this sense, is a different measure from the SES, because it is linked to the processes and interactions between guardians and children that regularly occur in the family routine. This measure also distances itself from the more frequent use of Pierre Bourdieu's (1988) concept of cultural capitalin educational stratification studies that focus on ownership ofvalued culturalobjects, participation in activities of so called high culture or possession of academic certificates (NOGUEIRA, 2021). 
Therefore, concerning the sociology of education, the HLE presents a new perspective, which focuses on the existence and frequency of processes and interactions in which guardians and children engage in the family routine and relate to child development.

The NSE is associated with the HLE and can explain how certain living conditions can expand or limit the ability of those responsible for promoting environments that enrich child development. However, the use of an HLE indicator in educational research, even with the introduction of controls on structural measures, such as income, parents' qualification and occupation, has helped to explain the variance in learning and the school trajectory of children, especially in preschool age (SAMMONS et al., 2008; SYLVA et al., 2010). Research interested in mapping the interactions between parents and children, seeking to understand how they relate to the development and performance of children in school, indicates that the HLE, in addition to SES measures, helps to understand inequalities at the beginning of the school trajectory. These inequalities manifest themselves early and can be measured from early childhood education (HOFF, 2006; MARTURANO, 2006; SYLVA et al., 2010; RODRIGUEZ; TAMIS-LEMONDA, 2011; ROWE, 2012).

In England, the longitudinal study Effective Provision of Pre-school and Primary Education (EPPE) followed approximately 3,000 children, aged 3 to 16 years, seeking to understand the effect of quality of care in early childhood education on children's development. One of the focuses of the study was to analyze the effects of HLE on the development of children in the language (literacy) and mathematics (numeracy) (SYLVA et al., 2010; TAGGART et al., 2011; SAMMONS et al., 2008). For this purpose, a scale was used based on items that asked the frequency (on a scale from 0 to 7) with which parents/guardians participated in seven activities with the children: reading books; trip to the library; play with numbers; painting and drawing; teaching of letters; teaching numbers; teaching songs/poems/rhymes. At baseline (initial measurement at age 3 years), children were assessed on verbal comprehension, vocabulary, image analysis, and questions using building blocks. They were reassessed at 5 years of age, and from 7 years onwards, children's cognitive performance was estimated using national standardized tests.

EPPE results indicated that a higher HLE, measured at age 3 years, was strongly associated with higher cognitive performance at age 5 years and its effects were stronger than income, SES, and/or parenting education. Controlling for children's demographic characteristics and family SES, the study observed an effect size of 0.42 in math and 0.69 in language for children who experienced high levels of HLE compared with those who experienced low levels. In addition, this investigation identified a positive and significant effect of HLE on self-regulation, prosocial behavior and hyperactivity at age 11 (SAMMONS et al., 2015).

Analyzes presented in Melhuish et al. (2008) using multinomial regression models found converging results: children with higher HLE were, at 5 years of age, more likely to have higher than expected results; children with a smaller HLE were more likely to have results below expectations. At 7 years of age (3rd year of primary school), the influence of the HLE, measured four years earlier, appeared to be smaller: it was only associated with the probability of the child being in the underperformance group compared to the expected performance group (MELHUISH et al., 2008). The authors of this study present some hypotheses for this weaker association: less precision in the cognitive development measure used at 7 years of age; less importance of family experiences; and new sources of influence, such as school ones, which would affect children's development. Furthermore, the authors caution that the effects of HLE on the development of children at age 7 observed in the analyses may express longterm effects of past experiences (on preschool entry) and current effects of the HLE. 
In the same direction, an important research carried out in the North American context on the prevention of reading difficulties, which uses a concept that is close to the HLE, identified that the differences in the "literacy environment" of the child's family context are related to the differences in performance in later reading (SNOW; BURNS; GRIFFIN, 1998). Also noteworthy is the specific importance of reading with children and reading materials at home for language growth and the pre-literacy process (RODRIGUEZ; TAMIS-LEMONDA, 2011).

The work by Rodriguez and Tamis-LeMonda (2011) analyzed HLE trajectory patterns over time. The study followed 1,852 families and performed HLE measurements when the children were $15,25,37$, and 63 months of age. To create the HLE indicator (with a range from 0 to 6), information was collected through visits to families' homes: activities that parents do with their children; suitable materials available (such as specific types of toys for each age group); and quality of interactions with the child. These measurements were grouped into six HLE trajectory patterns, some of which were consistently low, some were consistently high, and others were characterized by oscillations and were considered moderate. This investigation also measured the starting point of children concerning cognitive and language performance.

The results indicated that the HLE trajectory patterns are related to the sociodemographic characteristics of the families and the children's skills in vocabulary and literacy. Analyzes show that $70 \%$ of children whose families have a high and consistent trajectory pattern of HLE performed as expected or above expectations, according to US national norms, while only $7 \%$ of children in the trajectory low and moderate groups, achieved these exact results. The differences between these environments suggest a diversity of starting points in relation to children's knowledge and skills throughout preschool. The survey also revealed that, when children are 15 and 25 months old, the HLE is more associated with receptive language skills, while when they are older, it is related to the ability to identify letters and words. This alerts the fact that "consistent" environments continue to support children's development over time, as they correspond to the needs that emerge at each stage of development.

In the Brazilian context, the field of education-focused little on the impact of the learning environment provided by reference adults for children on their development in early childhood education. ${ }^{2}$ Research on the family-school relationship generally discusses the communication between these two worlds, the participation of guardians in the children's school life and the roles of early childhood education and the family (RODRIGUES; MUANIS, 2020). Brazilian studies on the relationship between the child's family environment and their school development, in general, are in the health field and do not have specific instruments that focus on the HLE of children in early childhood.

For example, a study that used a cross-sectional design found an association between children who enjoy better quality stimulation in the home environment and child development (ANDRADE et al., 2005). The sample included 350 children aged between 17 and 42 months and used the Home Observation for Measurement of the Environment Scale (HOME) inventory to measure stimulation in the family environment.

In an attempt to investigate associations between environmental factors and the prevalence of suspected language delay in children up to 6 years of age, Cachapuz and Halpern (2006) applied a 
questionnaire to the children's mothers. This one contemplated, among a series of questions, family stimuli at home and presented as a result that children who are little stimulated with reading, conversations and interaction at home are 2.88 times more likely to have a suspected test for language delay.

Due to the scarcity of cost-effective and adequate studies to understand the family environment, Marturano (2006) proposed the Inventory of Resources of the Family Environment Inventário de Recursos do Ambiente Familiar (RAF). ${ }^{3}$ In studies that use the inventory, the items that were most related to performance were: "access to trips, availability of books and toys, and opportunities for interaction with parents at home" (MARTURANO, 2006). The research by Ferreira and Barrera (2010), carried out with a group of thirty children between 5 and 6 years old, used this instrument and found that the presence of newspapers, magazines, books and toys, as well as activities shared with parents, including family meetings, was associated with what children know about reading and writing. Another survey investigated seventy children in the transition process from early childhood education to the 1st year of elementary school. The results indicated that the child's phonological awareness added to the resources of the family environment ${ }^{4}$ and positive parenting practices, it is a precursor of competence in the transition to the 1st year of Elementary School (MARTURANO; TRIVELLATO-FERREIRA, 2008).

In general, the results presented in Brazilian research show significant associations between the family environment and children's development. The studies seek to measure the general family environment, which results in a comprehensive measure encompassing a series of other factors (socioeconomic, health, related to pregnancy, possession of goods, etc.), differing from a measure of HLE with a greater focus on the home learning environment. It is noteworthy that, although the family environment has been measured in different ways in Brazilian studies, items related to adultchild interactions and stimulating parenting practices were consistently associated with development. In addition, it is worth noting that none of the Brazilian studies mentioned had simultaneously the following characteristics: being longitudinal, having a large sample and focusing on children in early childhood education.

\section{Study Design, Sample, Data Collection and Analysis}

This study used data from a longitudinal study that collected data between March 2017 and December 2018 with children enrolled in public schools in a Brazilian capital. The study aimed to obtain a "baseline" measure and follow the same children during preschool, ${ }^{5}$ aiming to understand school and non-school contextual factors associated with children's development. This article uses the data collected in the research in question and aims to discuss the relationship between the HLE provided by families and the development of children from the beginning in preschool and throughout this period of education.

The research selected a random sample of 46 schools, stratified by area and type of school, and approximately 2,700 children from a municipal education system. The longitudinal study included three waves of data collection on children: two collections in 2017, at the beginning and end of the school year, at 4/5 years of age; and a collection at the end of the 2018 school year, at 5/6 years. ${ }^{6}$ 
Fig. 1 below illustrates the design of the longitudinal study:

\begin{tabular}{|c|c|c|}
\hline Preschool I & Preschool I & Preschool II \\
\hline $\begin{array}{c}\mathrm{O}_{1} \\
4 \text { years }\end{array}$ & $\begin{array}{c}\mathrm{O}_{2} \\
4 / 5 \text { years }\end{array}$ & $\begin{array}{c}\mathrm{O}_{3} \\
5 / 6 \text { years }\end{array}$ \\
\hline 2017 & & 2018 \\
\hline
\end{tabular}

Source: Authors' elaboration.

Figure 1. Longitudinal study design

In waves 2 and 3 , children who entered the sample schools during preschool were included in the sample. To minimize attrition, the study also sought to monitor children who, in the course of it, migrated to other schools in the municipal public system. Thus, the number of children who participated in the longitudinal study increased from 2,716 in wave 1 to 2,848 and 3,552 in waves 2 and 3, respectively.

Data were collected on the children's cognitive development concerning fine and global motor coordination in each study wave. Data collection on cognitive development used an adaptation of the PIPS instrument, a tool tested and used for twenty years in the UK and other countries, developed by researchers at Durham University, England (TYMMS, 1999). The instrument was translated and adapted to the Brazilian context, and then a pre-test was carried out with 560 children in three cities (BARTHOLO et al., 2020a). The instrument measures two dimensions - language and mathematics - which are composed of the following sub-dimensions: a) writing; b) vocabulary; c) ideas about reading - evaluates concepts about print; c) phonological awareness; d) identification of letters; e) word recognition and reading; f) ideas about mathematics; g) counting and numbers; h) addition and subtraction without symbols; i) identification of forms; $j$ ) identification of numbers. Language and math scores were estimated from the cognitive test items of the PIPS test adaptation using Rasch measures (BOONE, 2016), using the Winsteps software.

In addition to the children's cognitive data, the longitudinal study collected information on the family background during waves 2 and 3, using questionnaires for parents and guardians. The demographic data of the children (age, skin color and gender) and the complementary data on the socioeconomic context of the family (parents' education and participation of the family in cash transfer program) were obtained from the Academic Management System of the Municipal Department of Education Sistema de Gestão Acadêmica da Secretaria Municipal de Educação (SGA/SME).

Table 1 shows the number of cases of children assessed in the first wave and assessed in two or more waves that also have information from the contextual questionnaires:

Table 1. Total number of children assessed in wave 1, in two or more waves and with a contextual questionnaire

\begin{tabular}{ccccc}
\hline & Wave $\mathbf{1}$ & Waves $\mathbf{1}$ and $\mathbf{2}$ & Waves $\mathbf{2}$ and $\mathbf{3}$ & Waves $\mathbf{1 , 2}$ and $\mathbf{3}$ \\
\hline Cognitive & 2,716 & 2,261 & 2,331 & 1,935 \\
\hline Cognitive + contextual & 1,722 & 1,718 & 1,841 & 1,550 \\
\hline
\end{tabular}

Source: Authors' elaboration. 
Analyzes included linear regressions to estimate the association between HLE and early preschool cognitive development, using the database of children who participated in wave 1 of the cognitive test and from whose parents/guardians we obtained questionnaires (1,722 cases). Multilevel linear regression models were estimated to observe the effect of HLE on children's learning during preschool. To minimize missing data, we used datasets with children assessed in waves 1 and 2 ( 1,718 cases) and waves 2 and 3 (1,841 cases) with answers to the questionnaires of parents/guardians.

\section{Home Learning Environment Measurement}

The questionnaire for the guardians addressed various aspects of the context of the child and their family, including questions about the education of parents/guardians, income, ownership of assets, participation in cash transfer programs, as well as characteristics of the child and the family's daily life, such as several absences, premature birth, the existence of books in the house, etc. The application of the questionnaire for the guardians took place during the children's entry and exit times, thus seeking to influence less in the school routine and reduce the time needed with the children's guardians.

For the composition of the HLE indicator, we used the responses of the guardiansfor two dimensions. The first had the adaptation of questions used in the EPPE study (SYLVA et al., 2010; SAMMONS, 2008). The items in the parent/guardian questionnaire asked whether a person over 15 years of age had participated, with the children, in the week before the study, in the following activities: 1) reading books or looking at pictures; 2) singing songs; 3 ) draw, paint or cut out; 4) playing with letters or alphabet; 5) counting objects or playing with numbers; 6) play with colors and/ or geometric shapes. ${ }^{7}$ In addition, the indicator considered whether the family had children's books and games and whether there were more than ten books (of any type) in the child's home. These last two questions deal with a more "structural" dimension of the concept and approach the measures related to the dimension of ownership of materials suitable for the age group used in the study by Rodriguez and Tamis-LeMonda (2011). The questions were included in the HLE measure because of their potential to indicate a family investment in education, in addition to not being directly linked to the family's income, such as other assets (car, washing machine, computer, etc.). The HLE indicator was elaborated using the Rasch model, using the Winsteps software from the described items. This procedure enabled the theoretical and empirical analysis of each item component of the indicator.

The unidimensionality test was performed with the items that make up the indicator to verify if they measured only one construct (latent trait). The test to verify the unexplained variance of the items must not present values greater than two eigenvalues to guarantee the unidimensionality of the indicator. The test result indicated that the items did not have values greater than two eigenvalues and, therefore, did not capture more than one dimension. For more details, see Linacre (2020).

Table 2 below shows the frequency of responses to the items that made up the HLE indicator and Fig. 2 shows the distribution of items and children in Wright's map: 
Table 2. Frequency of responses for each item of the HLE indicator ${ }^{8}$

\begin{tabular}{ccc}
\hline Items & Yes & No \\
\hline Has children's books & 86.2 & 13.0 \\
\hline Has children's games & 68.5 & 30.8 \\
\hline Read books or look at pictures & 72.0 & 28.0 \\
\hline Sang songs & 82.9 & 17.1 \\
\hline Drew, painted or cut out & 80.1 & 19.9 \\
\hline Played with letters or alphabet & 69.8 & 30.2 \\
\hline Counted objects or played with numbers & 68.3 & 31.7 \\
\hline Played with colors and/or geometric shapes & 64.1 & 35.9 \\
\hline Has more than ten books & 47.7 & 57.1 \\
\hline
\end{tabular}

Source: Authors' elaboration.

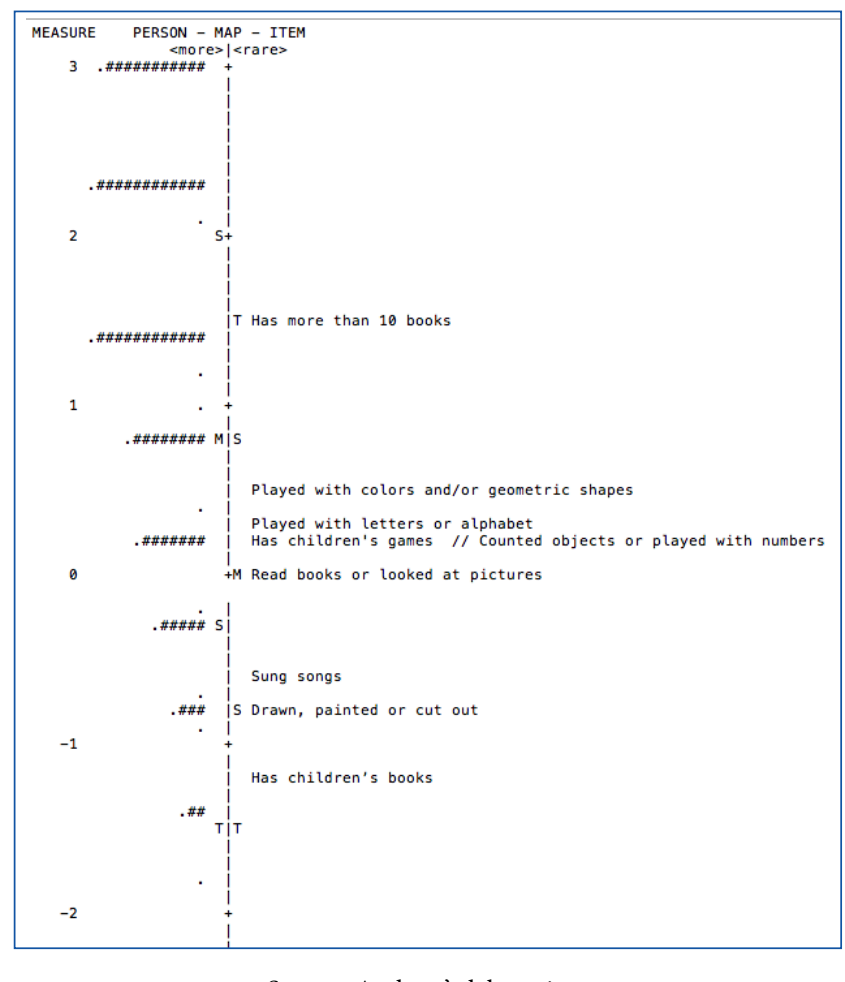

Source: Authors' elaboration.

Figure 2. Wright's map for the items that make up the HLE indicator

Table 2 indicates that the most common answers were that the family has children's books and that adults have drawn, painted, cut and/or sung songs with the children in the previous week. Less frequent responses among guardians were having more than ten books at home and playing with children with colors and/or geometric shapes and letters of the alphabet.

In Fig. 2, we observe Wright's map that plots the instrument's items according to their order of difficulty: the items are presented from the easiest (bottom) to the most complex (top of the map) or, in this case, from the HLE indicator, from the most frequent to the least frequent activities. On the left side of the map, the \# symbol is used to represent the individuals who were exposed to the test, each \# represents forty children (BOONE, 2016). The map confirms a theoretical progression in relation to the items, as activities closer to the "school world", such as playing with geometric shapes, letters or alphabets and numbers, are less frequent than drawing, painting, cutting and singing songs. 
It is important to note that having children's books is a prerequisite for reading with children and a large proportion of families indicated that they do not have more than ten books. A smaller number of family members reported reading or playing with letters in the family's daily routine.

Some important limitations appear from the item map, such as the high frequency of positive responses to children's activities. As this is an indirect measure, it is impossible to know if these activities took place and the duration and more qualitative characteristics of the activities carried out. As a result, the HLE indicator poorly discriminates against children who have a higher measure of the learning environment.

\section{Analysis and Results}

Table 3 presents the description of the variables used in the analyzes and the data sources used, and Table 4 shows the descriptive statistics of the study variables.

Table 3. Description of analyzed variables and their data sources

\begin{tabular}{|c|c|c|c|}
\hline \multirow{2}{*}{ Name } & \multirow{2}{*}{ Type } & Description & \multirow{2}{*}{ Source } \\
\hline & & Dependent Variables & \\
\hline Language & Continuous & Language measurement in waves 1,2 or 3 & Cognitive test \\
\hline \multirow[t]{3}{*}{ Mathematics } & Continuous & Math measurement in waves 1,2 or 3 & Cognitive test \\
\hline & & Explanatory Variables & \\
\hline & & Level 2 - school & \\
\hline $\begin{array}{l}\text { Low education } \\
\text { attainment of parents } \\
\text { ( School prop.) }\end{array}$ & Continuous & $\begin{array}{l}\text { Proportion of children whose parents do not } \\
\text { hold a high school or higher education degree }\end{array}$ & $\begin{array}{l}\text { Questionnaire for those } \\
\text { responsible and } \\
\text { SGA/SME }\end{array}$ \\
\hline $\begin{array}{l}\text { Color (Non White - } \\
\text { school prop.) }\end{array}$ & Continuous & Proportion of non white children & SGA/SME \\
\hline \multirow[t]{2}{*}{$\begin{array}{c}\text { Poverty } \\
\text { (prop. school) }\end{array}$} & Continuous & $\begin{array}{l}\text { Proportion of children whose parents participate } \\
\text { in the family cash transfer program }\end{array}$ & $\begin{array}{l}\text { Parent/guardian } \\
\text { questionnaire and } \\
\text { SGA/SME }\end{array}$ \\
\hline & & Level 1 - child & \\
\hline Language & Continuous & Language measurement in waves 2 or 3 & Cognitive test \\
\hline Mathematics & Continuous & Math measurement in waves 2 or 3 & Cognitive test \\
\hline HLE Indicator & Continuous & Home Learning Environment Indicator & $\begin{array}{l}\text { Parent/guardian } \\
\text { questionnaire }\end{array}$ \\
\hline $\begin{array}{l}\text { Low education } \\
\text { attainment }\end{array}$ & Dummy & $\begin{array}{l}\text { Indicates whether the child's parents/guardians } \\
\text { have not completed high school } \\
(0=\text { Yes; } 1=\mathrm{No})\end{array}$ & $\begin{array}{l}\text { SME and } \\
\text { Parent/guardian } \\
\text { Questionnaire }\end{array}$ \\
\hline Poverty & Dummy & $\begin{array}{l}\text { Indicates whether guardians are beneficiaries of } \\
\text { cash transfer programs } \\
(0=\text { No; } 1=\text { Yes })\end{array}$ & $\begin{array}{l}\text { SGA/SME and Parent/ } \\
\text { guardian Questionnaire }\end{array}$ \\
\hline Gender & Dummy & $\begin{array}{l}\text { Indicates the child's gender } \\
\qquad(0=\text { Girl; } 1=\text { Boy })\end{array}$ & SGA/SME \\
\hline Non white & Dummy & $\begin{array}{c}\text { Indicates the child's color } \\
\text { (declared by parents/guardians) } \\
(0=\text { White; } 1=\text { Non-white })\end{array}$ & SGA/SME \\
\hline Age & Continuous & Indicates age in years in waves 1,2 or 3 & SGA/SME \\
\hline
\end{tabular}

Source: Authors' elaboration. 
Table 4. Descriptive statistics of the variables used in the analyzes

\begin{tabular}{ccc}
\hline Variables & Mean & SD \\
\hline Language (wave 1) & -0.27 & 0.95 \\
\hline Language (wave 2) & 0.27 & 0.88 \\
\hline Language (wave 3) & 0.93 & 0.95 \\
\hline Mathematics (wave 1) & -2.77 & 1.32 \\
\hline Mathematics (wave 2) & -1.82 & 1.38 \\
\hline Mathematics (wave 3) & -0.62 & 1.55 \\
\hline $\begin{array}{c}\text { Low parental education attainment } \\
\text { (in proportion to school) }\end{array}$ & 0.46 & 0.13 \\
\hline Color (prop. black in school) & 0.63 & 0.11 \\
\hline Poverty (prop. school) & 0.30 & 0.09 \\
\hline HLE Indicator & 1.32 & 1.49 \\
\hline Low education & 0.47 & - \\
\hline Poverty & 0.43 & - \\
\hline Gender & 0.52 & - \\
\hline Non white & 0.62 & - \\
\hline Special needs & 0.03 & 0.35 \\
\hline Age (wave 1) & 4.39 & 0.35 \\
\hline Age (wave 2) & 5.06 &
\end{tabular}

Source: Authors' elaboration.

Table 5 shows the Pearson correlation between the HLE indicator and the children's language and mathematics measures in waves 1 (beginning of preschool), 2 (end of the first year of preschool) and 3 (end of the second year of preschool).

Table 5. Pearson correlation ( $\mathrm{r}$ ) between language and mathematics measures (waves 1, 2 and 3) and home learning environment (HLE)

\begin{tabular}{ccc}
\hline Medida & AAC & N \\
\hline Language (wave 1) & $0.192^{* * *}$ & 1699 \\
\hline Language (wave 2) & $0.208^{* * *}$ & 1930 \\
\hline Language (wave 3) & $0.222^{* * *}$ & 2271 \\
\hline Mathematics (wave 1) & $0.182^{* * *}$ & 1699 \\
\hline Mathematics (wave 2) & $0.220^{* * *}$ & 1930 \\
\hline Mathematics (wave 3) & $0.202^{* * *}$ & 2271 \\
\hline
\end{tabular}

Note: ${ }^{* * *} \mathrm{p}<0,001 ;{ }^{* *} \mathrm{p}<0,01 ;{ }^{*} \mathrm{p}<0,05$; Source: Authors' elaboration.

We observed a moderate correlation between math and language measures and HLE, ranging from 0.182 to $0.222 .{ }^{9}$ Correlations between HLE and cognitive measures in waves 2 and 3 seem stronger than correlations with baseline (measured at the beginning of preschool), suggesting a correlation of HLE with baseline and learning during preschool.

We then used linear regression models (Table 6) to estimate children's development in language and mathematics at the beginning of preschool (measures of wave 1), using explanatory variables of HLE (variable of interest) as well as control variables (education attainment of guardians, poverty, gender and age 
of children). Tables $6,7,8$ present the regression coefficients and their respective confidence intervals and Tables 9, 10 and 11, in the "Annex", indicate the effect size of the explanatory variables estimated from the coefficients obtained in the regression models.

Effect sizes are simple ways to report differences between two groups, rather than simply discussing statistical significance (HATTIE, 2009; HIGGINS, KOKOTSAKY, COE, 2014). In the present work, we calculate the effects according to the methodology developed by Tymms (2004). Thus, the continuous independent variables were standardized and the coefficients reported in effect sizes express the estimated differences for individuals with a standard deviation above and a standard deviation below the mean. To facilitate the interpretation of the results, we used the classification present in Higgins, Kokotsaky and Coe (2014): 1) effect sizes up to 0.18 are considered small;2) from 0.19 to 0.44 moderate; 3 ) effect sizes from 0.45 to 0.69 are high; and 4 ) effect sizes greater than 0.70 are very high. ${ }^{10}$

Table 6. Linear Regression Models Estimating Language and Mathematics at Preschool Entry

\begin{tabular}{|c|c|c|c|c|}
\hline & \multicolumn{2}{|c|}{ Language } & \multicolumn{2}{|c|}{ Mathematics } \\
\hline & Model 1 & Model 2 & Model 1 & Model 2 \\
\hline HLE & $\begin{array}{c}0.194^{* * *} \\
(0.147-0.240)\end{array}$ & $\begin{array}{c}0.143^{* * *} \\
(0.095-0.192)\end{array}$ & $\begin{array}{c}0.182^{* * *} \\
(0.136-0.229)\end{array}$ & $\begin{array}{c}0.103^{* * *} \\
(0.056-0.150)\end{array}$ \\
\hline Age & & $\begin{array}{c}0.322^{* * *} \\
(0.270-0.374) \\
\end{array}$ & & $\begin{array}{c}0.321^{* * *} \\
(0.271-0.371) \\
\end{array}$ \\
\hline Gender (boy) & & $\begin{array}{c}-0.202^{\star *} \\
(-0.294--0.110)\end{array}$ & & $\begin{array}{c}-0.034 \\
(-0.123-0.056)\end{array}$ \\
\hline Cor (negra) & & $\begin{array}{c}-0.092+ \\
(-0.187-0.002)\end{array}$ & & $\begin{array}{c}-0.157^{* * *} \\
(-0.249--0.65)\end{array}$ \\
\hline Low education & & $\begin{array}{c}-0.268^{* * *} \\
(-0.366--0.171)\end{array}$ & & $\begin{array}{c}-0.424^{* * *} \\
(-0.519--0.329)\end{array}$ \\
\hline Poverty & & $\begin{array}{c}-0.121^{*} \\
(-0.217--0.024)\end{array}$ & & $\begin{array}{c}-0.156^{* * *} \\
(-0.250--0.062)\end{array}$ \\
\hline Constant & $\begin{array}{c}-0.008 \\
(-0.54-0.039)\end{array}$ & $\begin{array}{c}0.308 \\
(0.207-0.409)\end{array}$ & $\begin{array}{c}-0.006 \\
(-0.053-0.040)\end{array}$ & $\begin{array}{c}0.349 \\
(0.251-0.447)\end{array}$ \\
\hline $\mathrm{N}$ & 1698 & 1590 & 1698 & 1590 \\
\hline $\mathrm{R} 2$ & 0.037 & 0.151 & 0.033 & 0.172 \\
\hline
\end{tabular}

Notes: ${ }^{* *} \mathrm{p}<0,001 ;{ }^{* *} \mathrm{p}<0,01 ;{ }^{*} \mathrm{p}<0,05 ;+\mathrm{p}<0,10$. The table presents the estimated coefficients and confidence intervals. Source: Authors' elaboration

The coefficients for the HLE are statistically significant in the four estimated models, showing the indicator's relationship with children's cognitive development at the beginning of compulsory education. The effect size for HLE is moderate for language (effect size of 0.308 ) in the model that includes control variables such as education attainment of parents/guardians, poverty, color, gender and age of children (model 2). In the model that estimates the mathematics measure at the preschool entrance, after the insertion of the control variables (model 2), the relationship with the HLE is smaller (effect size of 0.229), but still statistically significant and far from being negligible. These results converge with those found by Sammons et al. (2015), Rodriguez and Tamis-LeMonda (2011) and Melhuish et al. (2008), indicating that HLE can be a good measure for use in large-scale research in order to identify how the family context can impact the cognitive development of children at the beginning of schooling. We make a reservation that a measure of HLE is not intended to classify or judge the interactions between parents and children. It helps to understand how the learning environment provided by the family can boost the experiences of the school environment and, consequently, translate into school advantage for children. 
It is interesting to highlight that when measuring the HLE through activities performed, one may be measuring and encompassing a series of other factors in addition to explicit teaching, which exists in the activities themselves. That is, the indicator may be capturing key points for the development of young children, such as the existence of moments of interaction and affection between adults and children (PERES; BAUER, 2018), decontextualized conversations, joint attention to a given object and exchanges that involve many questions (HOFF, 2006; RODRIGUEZ; TAMIS-LEMONDA, 2011).

We also emphasize the age effect (measured in months) concerning cognitive development (effect sizes of 0.729 and 0.747 for language and math, respectively). This result converges with the intensity of the learning process in this age group and the strong maturation effect of children. Studies on the cognitive development of young children (FOX; LEVITT; NELSON, 2010; KNUDSEN, 2004) reveal that the plasticity of the human brain is greater in the first five years of life. This means that, in early childhood, it is easier and less costly for the brain to create new neural connections in the face of environmental factors. During this period, there is a critical window for developing sensory (vision, hearing) and cognitive capacities, such as language, attention, memory, planning, logical-mathematical reasoning and critical judgment (SHONKOFF; PHILLIPS, 2000; FOX; LEVITT; NELSON, 2010).

Tables 7 and 8 present results from multilevel linear regression models (child at level 1 and school at level 2), which estimate the relationship of HLE with children's cognitive development during the first and second years of preschool. For the first year of preschool, the dependent/interest variables used were language and mathematics measures calculated with data collected during wave 2 (end of the first year of preschool). For the second year of preschool, the models estimated the measurements collected during wave 3 (end of the second year of preschool). The models first include only the HLE indicator (models 1), then insert sociodemographic controls for children at level 1 and variables related to student composition at level $2 /$ school (models 2 ). Finally, they add the variable referring to the children's previous level of cognitive development (models 3 ).

In Table 7, we observe that the coefficients for the HLE indicator in the models that estimate language are statistically significant in the first and second years of preschool, even with the inclusion of variables related to the characteristics of the children and the student composition (models 2 ). In these models, effect sizes are moderate $(0.304$ for the first year in preschool and 0.331 for the second). Models 3 for first and second years in preschool have added value and include the previous language measure (measurement of waves 1 and 2, respectively), in addition to the control variables at the child and school levels present in model 2. In these models, the observed HLE association is smaller (effect size of 0.123 and 0.146 for the first and second years of preschool, respectively), but it is still statistically significant and pedagogically relevant. This result indicates that the HLE indicator is associated with baseline measures at the beginning of preschool and appears to be associated with children's cognitive development during the two years of this stage of education.

The association between HLE and children's cognitive development in the mathematics measure is shown in Table 8. The coefficients are similar to those obtained with the models that estimate language measures at the end of preschool's first and second years. The HLE has positive and statistically significant coefficients in all estimated models. The size of the association observed in the value-added models (models 3 ) are smaller at the end of the first and second years of preschool (effect sizes of 0.152 and 0.126 , respectively) compared to those observed in models 1 and 2, which 
Table 7. Multilevel linear regression models estimating language measures at the end of the first year (wave 2) and the end of the second year (wave 3) of preschool

\begin{tabular}{|c|c|c|c|c|c|c|}
\hline & \multicolumn{3}{|c|}{$1^{\circ}$ ano da pré-escola } & \multicolumn{3}{|c|}{ 2nd year of preschool } \\
\hline & Model 1 & Model 2 & Model 3 & Model 1 & Model 2 & Model 3 \\
\hline $\begin{array}{c}\text { Low education } \\
\text { attainment } \\
\text { (prop. in school) }\end{array}$ & & $\begin{array}{c}-0.040 \\
(-0.101-0.022)\end{array}$ & $\begin{array}{c}-0.015 \\
(-0.064-0.035)\end{array}$ & & $\begin{array}{c}0.003 \\
(-0.075-0.081) \\
\end{array}$ & $\begin{array}{c}0.010 \\
(-0.052-0.072)\end{array}$ \\
\hline $\begin{array}{c}\text { Color } \\
\text { (prop. of non } \\
\text { white in school) }\end{array}$ & & $\begin{array}{c}-0.010 \\
(-0.076-0.055)\end{array}$ & $\begin{array}{c}-0.009 \\
(-0.063-0.044)\end{array}$ & & $\begin{array}{c}-0.030 \\
(-0.111-0.051)\end{array}$ & $\begin{array}{c}-0.008 \\
(-0.074-0.058)\end{array}$ \\
\hline $\begin{array}{c}\text { Poverty } \\
\text { (prop. school) }\end{array}$ & & $\begin{array}{c}-0.057^{*} \\
(-0.125-0.012) \\
\end{array}$ & $\begin{array}{c}-0.041 \\
(-0.097-0.015)\end{array}$ & & $\begin{array}{c}-0.083^{*} \\
(-0.174-0.008)\end{array}$ & $\begin{array}{c}-0.031 \\
(-0.103-0.041) \\
\end{array}$ \\
\hline $\begin{array}{l}\text { Measure } \\
\text { (wave 1) }\end{array}$ & & & $\begin{array}{c}0.541^{\star * *} \\
(0.509-0.573)\end{array}$ & & & \\
\hline $\begin{array}{l}\text { Measure } \\
\text { (wave 2) }\end{array}$ & & & & & & $\begin{array}{c}0.676^{* * *} \\
(0.643-0.708)\end{array}$ \\
\hline HLE & $\begin{array}{c}0.166^{\star * *} \\
(0.126-0.205)\end{array}$ & $\begin{array}{c}0.123^{* \star \star} \\
(0.083-0.163)\end{array}$ & $\begin{array}{c}0.035^{\star} \\
(0.003-0.067)\end{array}$ & $\begin{array}{c}0.182^{\star * \star} \\
(0.143-0.221)\end{array}$ & $\begin{array}{c}0.141^{\star \star \star} \\
(0.100-0.182)\end{array}$ & $\begin{array}{c}0.043^{\star *} \\
(0.011-0.074)\end{array}$ \\
\hline Age & & $\begin{array}{c}0.262^{* * *} \\
(0.219-0.304) \\
\end{array}$ & $\begin{array}{c}0.090^{\star * *} \\
(0.055-0.125) \\
\end{array}$ & & $\begin{array}{c}0.249^{* * *} \\
(0.205-0.293) \\
\end{array}$ & $\begin{array}{c}0.073^{* * *} \\
(0.036-0.109) \\
\end{array}$ \\
\hline $\begin{array}{l}\text { Gender } \\
\text { (boy) }\end{array}$ & & $\begin{array}{c}-0.151^{\star \star} \\
(-0.227--0.075)\end{array}$ & $\begin{array}{c}-0.011 \\
(-0.070-0.048)\end{array}$ & & $\begin{array}{c}-0.189^{* * \star} \\
(-0.265--0.111)\end{array}$ & $\begin{array}{c}-0.080^{\star *} \\
(-0.137--0.020)\end{array}$ \\
\hline $\begin{array}{c}\text { Color } \\
\text { (non white) }\end{array}$ & & $\begin{array}{c}-0.100^{\star \star} \\
(-0.179--0.019)\end{array}$ & $\begin{array}{c}-0.048^{\star} \\
(-0.109-0.013)\end{array}$ & & $\begin{array}{c}-0.086^{\star} \\
(-0.166--0.005)\end{array}$ & $\begin{array}{c}-0.040 \\
(-0.101-0.020)\end{array}$ \\
\hline $\begin{array}{c}\text { Low education } \\
\text { attainment }\end{array}$ & & $\begin{array}{c}-0.233^{* * *} \\
(-0.315--0.151)\end{array}$ & $\begin{array}{c}-0.118^{* * *} \\
(-0.182-0.053)\end{array}$ & & $\begin{array}{c}-0.304^{* * *} \\
(-0.388-0.219)\end{array}$ & $\begin{array}{c}-0.120^{* * *} \\
(-0.183--0.056)\end{array}$ \\
\hline Poverty & & $\begin{array}{c}-0.059 \\
(-0.140-0.021)\end{array}$ & $\begin{array}{c}-0.020 \\
(-0.082-0.043)\end{array}$ & & $\begin{array}{c}-0.124^{\star \star} \\
(-0.206-0.042)\end{array}$ & $\begin{array}{c}-0.068^{\star} \\
(-0.130--0.006)\end{array}$ \\
\hline LogLikelihood & -2477.868 & -2152.754 & -1317.062 & -3058.074 & -2407.296 & -1417.498 \\
\hline AIC & 4903.736 & 4329.508 & 2660.124 & 6124.149 & 4838.591 & 2860.996 \\
\hline N Students & 1929 & 1772 & 1498 & 2269 & 1895 & 1575 \\
\hline N School & 46 & 46 & 46 & 46 & 46 & 46 \\
\hline
\end{tabular}

do not include control of the previous measure. Still, the coefficients in Models 3 remain statistically significant, again pointing out that the HLE indicator is associated with children's development during preschool. It is noteworthy that, without the inclusion of the control of the previous measures (wave 1 for the first year of preschool and wave 2 for the second), the models would overestimate a potential effect of HLE on children's language and math development during preschool. The results reinforce the importance of studies with longitudinal designs that allow the construction of value-added models to estimate the impact of HLE and/or the effect of school on children's development.

The results observed in the Brazilian context converge with longitudinal studies carried out with children of this age group in other contexts, such as the EPPE (SYLVA et al., 2010; SAMMONS et al., 2015; MELHUISH et al., 2008) and the one carried out by Rodriguez and Tamis-LeMonda 
(2011).

Table 8. Multilevel linear regression models estimate math measures at the end of the first year (wave 2) and the end of preschool's second rear (wave 3).

\begin{tabular}{|c|c|c|c|c|c|c|}
\hline & \multicolumn{3}{|c|}{ 1st year of preschool } & \multicolumn{3}{|c|}{ 2nd year of preschool } \\
\hline & Model 1 & Model 2 & Model 3 & Model 1 & Model 2 & Model 3 \\
\hline \multirow{2}{*}{$\begin{array}{l}\text { Low education } \\
\text { attainment (prop. } \\
\text { in school) }\end{array}$} & & -0.063 & 0.007 & & -0.036 & 0.001 \\
\hline & & $(-0.154-0.028)$ & $(-0.056-0.071)$ & & $(-0.136-0.064)$ & $(-0.064-0.066)$ \\
\hline \multirow{2}{*}{$\begin{array}{c}\text { Color } \\
\text { (prop. of non } \\
\text { white in school) }\end{array}$} & & -0.038 & -0.021 & & -0.042 & -0.008 \\
\hline & & $(-0.135-0.060)$ & $(-0.089-0.049)$ & & $(-0.147-0.064)$ & $(-0.077-0.061)$ \\
\hline \multirow{2}{*}{$\begin{array}{c}\text { Poverty } \\
\text { (prop. school) }\end{array}$} & & -0.036 & -0.036 & & -0.030 & 0.001 \\
\hline & & $(-0.138-0.066)$ & $(-0.105-0.033)$ & & $(-0.144-0.084)$ & $(-0.070-0.071)$ \\
\hline \multirow{2}{*}{$\begin{array}{l}\text { Measure } \\
\text { (wave 1) }\end{array}$} & & & $0.948^{\star * *}$ & & & \\
\hline & & & $(0.896-0.999)$ & & & \\
\hline \multirow{2}{*}{$\begin{array}{l}\text { Measure } \\
\text { (wave 2) }\end{array}$} & & & & & & $1.123^{\star * *}$ \\
\hline & & & & & & $(1.071-1.174)$ \\
\hline \multirow{2}{*}{ HLE } & $0.273^{* * *}$ & $0.193^{* * *}$ & $0.068^{\star *}$ & $0.279^{* * *}$ & $0.225^{\star * *}$ & $0.059^{*}$ \\
\hline & $(0.212-0.334)$ & $(0.131-0.256)$ & $(0.019-0.117)$ & $(0.215-0.342)$ & $(0.158-0.292)$ & $(0.009-0.109)$ \\
\hline \multirow{2}{*}{ Age } & & $0.435^{\star * *}$ & $0.145^{\star * *}$ & & $0.483^{\star * *}$ & $0.120^{\star * *}$ \\
\hline & & $(0.370-0.501)$ & $(0.091-0.199)$ & & $(0.412-0.554)$ & $(0.062-0.176)$ \\
\hline \multirow{2}{*}{$\begin{array}{c}\text { Gender } \\
\text { (boy) }\end{array}$} & & -0.081 & 0.044 & & $0.105^{\star}$ & $0.178^{\star \star \star}$ \\
\hline & & $(-0.198-0.036)$ & $(-0.047-0.134)$ & & $(-0.021-0.230)$ & $(0.086-0.270)$ \\
\hline \multirow{2}{*}{$\begin{array}{c}\text { Color } \\
\text { (non white) }\end{array}$} & & $-0.214^{\star \star *}$ & -0.064 & & $-0.147^{\star}$ & -0.011 \\
\hline & & $(-0.338--0.091)$ & $(-0.158-0.032)$ & & $(-0.278--0.016)$ & $(-0.107-0.085)$ \\
\hline \multirow{2}{*}{$\begin{array}{c}\text { Low education } \\
\text { attainment }\end{array}$} & & $-0.467^{\star * *}$ & $-0.154^{\star *}$ & & $-0.434^{* * *}$ & -0.065 \\
\hline & & $(-0.593--0.338)$ & $(-0.254--0.053)$ & & $(-0.570--0.296)$ & $(-0.165-0.037)$ \\
\hline \multirow{2}{*}{ Poverty } & & $-0.164^{*}$ & -0.040 & & $-0.211^{\star * *}$ & $-0.095^{*}$ \\
\hline & & $(-0.289--0.039)$ & $(-0.136-0.057)$ & & $(-0.346--0.078)$ & $(-0.194-0.002)$ \\
\hline LogLikelihood & -3297.020 & -2924.152 & -1960.340 & -4153.619 & -3320.895 & -2125.255 \\
\hline AIC & 6602.040 & 5872.303 & 3946.680 & 8315.238 & 6665.790 & 4276.511 \\
\hline N Students & 1929 & 1772 & 1498 & 2269 & 1895 & 1575 \\
\hline N School & 46 & 46 & 46 & 46 & 46 & 46 \\
\hline
\end{tabular}

\section{Final Considerations}

In Brazil, most studies in the area of early childhood education on the family-school relationship focus on the divergences between the conceptions of teachers and guardians about the education of young children (RODRIGUES; MUANIS, 2020). Regarding the production in the field of sociology of education, we observed few studies that deal with extra-school factors associated with the development of children in early childhood education. Our study presents an innovative analysis, not only for studying how social inequalities appear at the beginning of compulsory schooling but also for using an indicator of HLE, which sought to capture more procedural aspects of adultchild interaction, in addition to measures of structural factors related to children socioeconomic 
background, which are most commonly used in studies in the field of sociology of education in Brazil. The results found indicate that the HLE proved to be relevant to understanding the starting point of children and continued to be a variable that contributes to explaining growth during the first two years of compulsory schooling, even when taking into account children with similar sociodemographic characteristics (color, age and gender of children, education level of those responsible for them and poverty). This result points to the relevance of including characteristics of the family's routine and dynamics in this equation, as the child's reference adults are part of their closest context and can provide significant learning opportunities.

It is noteworthy that the concept of a home learning environment cannot be confused with homeschooling (home education), as it has been used precisely to improve the accuracy of analyzes of the child's trajectory and processes in the education system. Furthermore, discussing educational inequalities at the beginning of schooling requires attention to how family and school environments converse and the adaptations children need to make to move in these two environments. This debate needs a deeper approach to avoid simplistic interpretations that aim to educate the family environment or blame families for existing inequalities, making them responsible for compensating for deep social issues. Improvements in HLE do not occur in isolation from the larger social context and community of which the families are part. In this sense, an important contribution of this work and studies that deal with HLE is to encourage and inform the development of public policies and school practices that support and guide families as educators and caregivers, aiming at greater success in the children's school experience. Interventions that seek to stimulate the HLE of children must take into account the various limitations and difficulties encountered by families, such as parents' long working hours, situations of extreme poverty, the mental health of family members, domestic violence and violence around the residence, housing quality etc. (SMEES; SAMMONS, 2017; BRITTO et al., 2015). Such a context requires that HLE promotion strategies are accompanied by broader intersectoral policies to support children and their families. In this sense, we draw attention to some studies that evaluated the impact of programs focused on stimulating interactions and activities carried out in the family context. The topics covered are diverse, such as healthy habits and nutrition, health care, the importance of breastfeeding, the need for affection and positive bonds, children's enormous learning capacity, and how to have interactions that encourage their development (PERES; BAUER, 2018 ). Some programs that have a more specific focus on improving interactions and activities carried out in the family context have found positive results on children's cognitive development in preschool (BARLETT et al., 2016; BRITTO et al., 2015; WEISLEDER et al., 2018).

In turn, early childhood education institutions have a significant window of opportunity to dialogue with families about the learning and development of children. Programs aimed at empowering schools and providing conditions for them to support families in creating learning environments at home can be a fundamental part of implementing policies that seek to achieve HLE. Considering that the expansion and elaboration of regulatory frameworks and curriculum guidelines for early childhood education in Brazil are very recent, several parentes/guardians had little or no contact or experience with this level of education and its specific pedagogical practices, guided by interactions and play. This reality reinforces the role of early childhood education centers in developing strategies to promote closer family-school relationships and guiding parents/guardians for carrying out activities such as reading children's books and other recreational activities, including playing with rhymes, letters, and numbers others.

Finally, understanding the relationship between HLE and children's development at the 
beginning of compulsory education becomes even more relevant in the context of the pandemic. The long period of school closure experienced in the Brazilian context, as well as the limitations already observed by research for the implementation of remote learning (CAMPOS; VIEIRA, 2021; BARBERIA; CANTANELLI; SCHMALZ, 2021), presented barriers for schools to offer learning opportunities for children, especially those in more vulnerable backgrounds. Therefore, we assume that the opportunities offered by families will gain even greater weight as predictors of children's development during the pandemic and, therefore, we can expect an intensification of existing inequalities at the beginning of compulsory schooling (BARTHOLO et al., 2020b; KOSLINSKI; BARTHOLO, 2020). Again, this study adds to the existing evidence on child development that suggests the importance of thinking about intersectoral public policies that help families support children, especially when it comes to groups in social vulnerability.

\section{Authors' Contributions}

Problematization and conceptualization: Koslinski MC, Gomes RC, Rodrigues BLC; Methodology: Koslinski MC, Bartholo TL, Andrade FM; Analysis: Koslinski MC, Andrade FM; Writing: Koslinski MC, Gomes RC, Rodrigues BLC, Andrade FM, Bartholo TL.

\section{Notes}

1. The Geres survey (2005) was the main large-scale longitudinal study in education in the Brazilian context. Conducted for over fifteen years, the research focused on the early years of Elementary School(BROOKE; BONAMINO, 2011).

2. For example, a recent study by Carvalho and Nogueira (2020), developed in the field of sociology of education, with children aged 3 to 11 years, identified that, among families with more significant cultural capital, children had a greater organization of room space, in compliance with the demands of the school culture. However, the study does not attempt to relate such practices to children's development.

3. The instrument seeks to identify resources from the family environment that can contribute to academic learning at the beginning of elementary school in multiple dimensions, such as: outings, toys, books, predictable activities (regular family routines) and parenting practices.

4. Measured by seven RAF items: what the child does when not at school; trips carried out in the last twelve months; activities shared with parents at home; a variety of toys and books available; timed daily routines; times of the day and week when the family gets together.

5. Throughout the text, we use the terms "preschool" and "early childhood education". We recognize the debate in the field and the defense of the term early childhood education. However, we think it is essential to indicate the study's scope, which does not include children aged 0 to 3 . The present study focused on children who were 4 years old in 2017 and were, therefore, at the beginning of compulsory schooling, according to Constitutional Amendment n. 59, of November 11, 2009.

6. For more details about the sample, see the Author (KOSLINSKI; BARTHOLO, 2019; BARTHOLO et al., 2020a;).

7. We assume that the HLE can be influenced by several factors: the socioeconomic origin of the child; previous experience and knowledge of the family about early childhood education; educational programs; school actions to encourage interactions between guardians; among other factors. However, in the questionnaire, we sought to understand only whether or not someone in the family carried out the activities previously described with the child, without identifying whether the activities had been initiatives of the families themselves or carried out based on school guidance. 
8. Items where the sum of responses does not complete $100 \%$ indicate missing data. The absence of an answer may have been due to a lack of knowledge about a certain activity having been performed, about the possession of items or by choosing not to answer that question.

9. Correlations can be considered from low to moderate, but it is essential to highlight that they are consistent over time (three measures of cognitive development) and statistically significant. When compared with other findings in the field of education that associate measures of the family background with cognitive development, we observe that the size of the coefficients is relevant from the pedagogical and children developmental points of view.

10. The authors suggest an interpretation of effect sizes in months of school progress, considering the effect size of a standard deviation is equivalent to one year of instruction in elementary education.

\section{References}

ANDRADE, S. A. et al. Ambiente familiar e desenvolvimento cognitivo infantil: uma abordagem epidemiológica. Revista de Saúde Pública, São Paulo, v. 39, n. 4, p. 606-611, 2005. https://doi.org/10.1590/ S0034-89102005000400014

BARBERIA, L. G.; CANTANELLI, L. G.; SCHMALZ, P. H. S. Uma avaliação dos programas de educação pública dos estados e capitais brasileiras durante a pandemia do COVID-19. [S. 1.]: FGV/EESP/CLEAR, 2021. Available at: https://remote-learning-in-the-covid-19-pandemic-v-1-0-portuguese-diagramado-1.pdf. Accessed on: 5 may 2021.

BARTHOLO, T. L. et al. What do children know upon entry to pre-school in Rio de Janeiro? Ensaio: Avaliação e Políticas Públicas em Educação, Rio de Janeiro, v. 28, n. 107, p. 1-22, 2020a. https://doi.org/10.1590/ S0104-40362019002702071

BARTHOLO, T. L. et al. The use of cognitive instruments for research in early childhood education: constraints and possibilities in the Brazilian context. Pro-Posições, Campinas, v. 31, 2020b, p. 1-24. https:// doi.org/10.1590/1980-6248-2018-0036

BARTLETT, J. et al. Compendium of parenting interventions. Washington, D.C.: National Center on Parent, Family, and Community Engagement/Office of Head Start/U.S. Department of Health \& Human Services, 2016.

BONAMINO, A. M. C. et al. Os efeitos das diferentes formas de capital no desempenho escolar: um estudo à luz de Bourdieu e de Coleman. Revista Brasileira de Educação, Rio de Janeiro, v. 15, n. 45, p. 487-499, 2010. https://doi.org/10.1590/S1413-24782010000300007

BOONE, W. J. Rasch analysis for instrument development: why, when, and how? CBE Life Sciences Education, Rockville Pike, v. 15, n. 4, p. 1-7, 2016. https://doi.org/10.1187/cbe.16-04-0148

BOURDIEU, P. Os três estados do capital cultural. In: NOGUEIRA, M. A.; CATANI, A. (orgs.). Escritos de educação. Petrópolis: Vozes, 1988. p. 71-79.

BRASIL. Lei n. 13.005, de 24 de junho de 2014. Aprova o Plano Nacional de Educação - PNE e dá outras providências. Brasília, DF: Presidência da República, 2014.

BRITTO, P. et al. A systematic review of parenting programmes for young children in low- and middleincome countries. New York: United Nation's Children Emergency Fund/UNICEF, 2015. 
BRONFENBRENNER, U. Ecological systems theory. In: R. VASTA (ed.), Annals of child development. Greenwich, CT: JAI Press, 1989. v. 6, p. 187-249.

BRONFENBRENNER, U.; MORRIS, P. A. The bioecological model of human development. In: DAMON, W.; LERNER, R. M. (eds.), Handbook of child psychology: theoretical models of human development. 6. ed. New York: John Wiley, 2006.

BROOKE, N.; SOARES, J. F. (orgs.). Pesquisa em eficácia escolar: origem e trajetórias. Belo Horizonte: Editora UFMG, 2008.

BROOKE, N.; BONAMINO, A. (orgs.). Geres 2005: razões e resultados de uma pesquisa longitudinal sobre a eficácia escolar. Rio de Janeiro: Walprint, 2011.

CACHAPUZ R. F.; HALPERN R. A influência das variáveis ambientais no desenvolvimento da linguagem em uma amostra de crianças. Revista da AMRIGS, Porto Alegre, v. 40, n.4, p. 292-301, 2006.

CAMPOS, M. M.; VIERA, L. F. Covid-19 and early childhood in Brazil: impacts on children's well-being, education and care. European Early Childhood Education Research Journal, Abingdon, v. 29, Jan. 2021, p. 1-16. https://doi.org/10.1080/1350293X.2021.1872671

CARVALHO, C. N.; NOGUEIRA, M. A. "Nascer em berço de ouro": o quarto infantil como instância socializatória. Educação \& Sociedade, Campinas, v. 41, p. 1-19, 2020. https://doi.org/10.1590/ES.234058

CASTRO, C. Avaliação do aprendizado no ciclo de alfabetização de alunos da rede municipal do Rio de Janeiro. 2016. Dissertação (Mestrado em População, Território e Estatísticas Públicas) - Instituto Brasileiro de Geografia e Estatística. Escola Nacional de Ciência Estatística, Rio de Janeiro, 2016.

CRAHAY, M.; BAYE, A. Existem escolas justas e eficazes? Esboço de resposta baseado no PISA 2009. Cadernos de Pesquisa, São Paulo, v. 43, n. 150, p. 858-883, 2013. https://doi.org/10.1590/S0100-15742013000300007

FERREIRA, S. H. A.; BARRERA, S. D. Ambiente familiar e aprendizagem escolar em alunos da educação infantil. Psico, Porto Alegre, v. 41, n. 4, p. 462-472, 2010.

FOX S.; LEVITT, P.; NELSON C. A. How the timing and quality of early experiences influence the development of brain architecture. Child Development, Rockville Pike, v. 81, n. 1, p. 28-40, 2010. https:// doi.org/10.1111/j.1467-8624.2009.01380.x

FRANCO, C. et al. Qualidade e equidade em educação: reconsiderando o significado de "fatores intraescolares”. Ensaio: Avaliação e Políticas Públicas em Educação, Rio de Janeiro, v. 15, n. 55, p. 277-297, 2007. https://doi.org/10.1590/S0104-40362007000200007

HATTIE, J. Visible learning: a synthesis of over 800 meta-analyses relating to achievement. New York: Routledge, 2009.

HIGGINS, S.; KOKOTSAKY, D.; COE, R. Technical appendices. Teaching and learning toolkit. [S. 1.]: The Sutton Trust/Education Endowment Foundation, feb. 2014. Available at: www.cplp.eu/en/ download/1404046919/?at=1. Accessed on: 3 feb. 2019.

HOFF, E. How social contexts support and shape language development. Developmental Review, Orlando, v. 26, n. 1, p. 55-88, 2006. https://doi.org/10.1016/j.dr.2005.11.002 
HOFF, E. The specificity of environmental influence: socioeconomic status affects early vocabulary development via maternal speech. Child Development, Rockville Pike, v. 74, n. 5, p. 1368-1378, 2003. https:// doi.org/10.1111/1467-8624.00612

KNUDSEN, E. I. Sensitive periods in the development of the brain and behavior. Journal of Cognitive Neuroscience, Cambridge, MA, v. 16, n. 8, p. 1412-1425, 2004. https://doi.org/10.1162/0898929042304796

KOSLINSKI, M. C.; BARTHOLO, T. L. Impacto dos espaços de desenvolvimento infantil no primeiro ano na pré-escola. Estudos em Avaliação Educacional, São Paulo, v. 30, n. 73 p. 280-311, 2019. https://doi. org/10.18222/eae.v30i73.5850

KOSLINSKI, M. C.; BARTHOLO, T. L. Desigualdades de oportunidades educacionais no início da trajetória escolar no contexto brasileiro. Lua Nova, São Paulo, n. 110, p. 215-245, 2020. https://doi. org/10.1590/0102-215245/110

LINACRE, J. M. Winsteps Rasch measurement computer program user's guide. Oregon: Beaverton, 2020.

MARTURANO, E. M. O inventário de recursos do ambiente familiar. Psicologia: Reflexão e Crítica, Porto Alegre, v. 19, n. 3, p. 498-506, 2006. https://doi.org/10.1590/S0102-79722006000300019

MARTURANO, E. M. et al. Effects of the home learning environment and preschool center experience upon literacy and numeracy development in early primary school. Journal of Social Issues, Malden, v. 64, n.1, p. 95-114, 2008. https://doi.org/10.1111/j.1540-4560.2008.00550.x

MARTURANO, E. M.; TRIVELLATO-FERREIRA, M. C. Recursos da criança, da família e da escola predizem competência na transição da $1^{a}$ série. Revista Interamericana de Psicología/Interamerican Journal of Psychology, Porto Alegre, v. 42, n. 3, p. 549-558, 2008.

MELHUISH, E. et al. Effects of the Home Learning Environment and preschool center experience upon literacy and numeracy development in early primary school. Journal of Social Issues, Maiden, v. 64, n. 1, p. 95-114, 2008. https://doi.org/10.1111/j.1540-4560.2008.00550.x

NOGUEIRA, M. A. O capital cultural e a produção das desigualdades escolares contemporâneas. Cadernos de Pesquisa, São Paulo, p. 1-13, v. 51, 2021. https://doi.org/10.1590/198053147468

NATIONAL LITERACY TRUST; NATIONAL CHILDREN'S BUREAU; PEEPLE; FOUNDATION YEARS TRUST. Home Matters: making the most of the home learning environment. Guidance for schools, nurseries, local authorities and public health partners. London: National Children's Bureau, 2018. Available at: https://www.ncb.org.uk/sites/default/files/field/attachment/HLE_doc.pdf. Accessed on: 10 nov. 2020

OPNE [OBSERVATÓRIO DO PLANO NACIONAL DE EDUCAÇÃO]. Observatoriodopne.org.br, [s. d.]. Available at: https://www.observatoriodopne.org.br. Accessed on: 10 nov. 2020.

PERES, A., BAUER, M. Da ciência à prática: os programas de apoio ao desenvolvimento infantil na América Latina. São Paulo: Cross Content, 2018.

RAIKES, H. et al. Mother-child book reading in low-income families: correlates and outcomes during the first three years of life. Child Development, Rockville Pike, v. 77, n. 4, p. 924-953, 2006. https://doi. org/10.1111/j.1467-8624.2006.00911.x 
RODRIGUES, B. L. C.; MUANIS, M. C. A relação família e escola na educação infantil. Revista Contemporânea de Educação, Rio de Janeiro, v. 15, n. 33, p. 73-91, maio/ago. 2020. https://doi.org/10.20500/v15i33.37395

RODRIGUEZ, E. T. et al. The formative role of home literacy experiences across the first three years of life in children from low-income families. Journal of Applied Developmental Psychology, Amsterdam, v. 30, n. 6, p. 677-694, 2009. https://doi.org/10.1016/j.appdev.2009.01.003

RODRIGUEZ, E. T.; TAMIS-LEMONDA, C. S. Trajectories of the home learning environment across the first 5 years: associations with children's vocabulary and literacy skills at prekindergarten. Child Development, Rockville Pike, v. 82, n. 4, p. 1058-1075, 2011. https://doi.org/10.1111/j.1467-8624.2011.01614.x

ROWE, M. L. A longitudinal investigation of the role of quantity and quality of child-directed speech in vocabulary development: child-directed speech and vocabulary. Child Development, Rockville Pike, v. 83, n. 5, p. 1762-1774, 2012. https://doi.org/10.1111/j.1467-8624.2012.01805.x

SAMMONS, P. et al. Influences on children's attainment and progress in key stage 2: cognitive outcomes in year 6. Effective pre-school and primary education 3-11 Project (EPPE 3-11). Research Report n. DCSF-RR048. Nottingham: Department for Children, Schools and Families, 2008.

SAMMONS, P. et al. The long-term role of the home learning environment in shaping students' academic attainment in secondary school. Journal of Children's Services, [s. 1.], v. 10, n. 3, p. 189-201, 2015. https://doi. org/10.1108/JCS-02-2015-0007

SHONKOFF, J. P.; PHILLIPS, D. A. (eds.). From neurons to neighborhoods: the science of early childhood development. Washington, DC: The National Academies Press, 2000.

SIRIN, S. R. Socioeconomic status and academic achievement: a meta-analytic review of research. Review of Educational Research, Washington, DC, v. 75, n. 3, p. 417-453, 2005.https://doi.org/10.3102/00346543075003417

SMEES, R; SAMMONS, P. What role does the home learning environment play in supporting good child development in the early years and positive outcomes in later life? London: Action for Children, 2017.

SNOW, C. E.; BURNS, S.; GRIFFIN, P. Preventing reading difficulties in young children. Washington, DC: National Academy Press, 1998.

SOARES, J. F. Qualidade e equidade na educação básica brasileira: a evidência do SAEB-2001. Archivos Analíticos de Políticas Educativas/Education Policy Analysis Archives, Tempe, v. 12, n. 38, p. 1-24, 2004.

SOARES, T. M. et al. Modelos de valor agregado para medir a eficácia das escolas Geres. Ensaio: Avaliação e Políticas Públicas em Educação, Rio de Janeiro, v. 25, n. 94, p. 59-89, 2017. https://doi.org/10.1590/ S0104-40362017000100003

SYLVA, K. et al. Early childhood matters: evidence from the effective pre-school and primary education project. London: Routledge, 2010.

TAGGART, B. et al. O poder da pré-escola: evidências de um estudo longitudinal na Inglaterra. Cadernos de Pesquisa, São Paulo, v. 41, n. 142, p. 68-99, 2011. https://doi.org/10.1590/S0100-15742011000100005

TYMMS, P. Baseline assessment and monitoring in primary schools: achievements, attitudes and value-added indicators. London: David Fulton, 1999. 
TYMMS, P. Effect sizes in multilevel models. In: SCHAGEN, I.; ELLIOT, K. (orgs.). But what does it mean? The use of effect sizes in educational research. Slough, UK: National Foundation for Educational Research, 2004.

WEISLEDER, A. et al. Reading aloud and child development: a cluster-randomized trial in Brazil. Pediatrics, Evanston, v. 141, n. 1, 2018. https://doi.org/10.1542/peds.2017-0723

\section{About the Authors}

Mariane Campelo Koslinski holds a B Sc in Sociology from the London School of Economics and a Ph.D. in Sociology from Universidade Federal do Rio de Janeiro (UFRJ), with a period as a Visiting Scholar at Columbia University. She is currently an associate professor at Faculdade de Educação and the Postgraduate Program in Education and coordinator of the Laboratório de Pesquisa em Oportunidades Educacionais (Educational Opportunities Research Laboratory), both at UFRJ. Has experience in research in the field of sociology of education, with an emphasis on educational assessment; analysis of educational policies; inequalities of educational opportunities; and socio-spatial segregation and educational inequalities.

Renata Corrêa Gomes has a degree in Pedagogy from Universidade Federal do Rio de Janeiro (UFRJ) and is a Master's student at the Graduate School of Education at Stanford University. She has experience in research in the areas of teacher education, educational assessment and educational opportunities inequalities.

Blenda Luize Chor Rodrigues is a doctoral student at the University of North Carolina at Greensboro and has a degree in Pedagogy from Universidade Federal do Rio de Janeiro (UFRJ). She researches the relationships between the quality of early childhood education centers and young children's cognitive and socio-emotional development. She has experience in designing, translating and adapting instruments to measure the quality of the contexts provided by early childhood education centers.

Felipe Macedo de Andrade Holds a degree in Physical Education and a PhD in Education, both from the Universidade Federal do Rio de Janeiro (UFRJ). Currently, he is a professor at the Colégio de Aplicação (College of Application) at UFRJ and coordinator of the Curso de Especialização Saberes e Práticas na Educação Básica (CESPEB) (Knowledge and Practices in Basic Education Specialization Course)with an emphasis on School Physical Education. Develops research in the sociology of education with an emphasis on large-scale assessment, accountability policies, and the processes of appropriation of the use of data by schools.

Tiago Lisboa Bartholo holds a PhD in education from Universidade Federal do Rio de Janeiro (UFRJ). $\mathrm{He}$ is currently a professor in the Postgraduate Program in Education at Universidade Federal do Rio de Janeiro (PPGE-UFRJ) and the Colégio de Aplicação at UFRJ (CAp-UFRJ). Researcher at the Laboratório de Pesquisa em Oportunidades Educacionais at the same institution. Has experience with studies in the field of sociology of education, emphasizing the theme of educational inequalities, school segregation; and impact evaluation of educational programs and policies. 


\section{Appendices}

Table 9. Linear regression models estimating language and math at the preschool entrance (effect sizes)

\begin{tabular}{|c|c|c|c|c|}
\hline & \multicolumn{2}{|c|}{ Language } & \multicolumn{2}{|c|}{ Mathematics } \\
\hline & Model 1 & Model 2 & Model 1 & Model 2 \\
\hline HLE & $0.394^{* * *}$ & $0.308^{* * *}$ & $0.372^{* * *}$ & $0.229^{* * *}$ \\
\hline Age & & $0.729^{* * *}$ & & $0.747^{* * *}$ \\
\hline Gender (boy) & & $-0.218^{* * *}$ & & -0.038 \\
\hline Color (non white) & & $-0.099^{+}$ & & $-0.173^{* * *}$ \\
\hline $\begin{array}{c}\text { Low parental education } \\
\text { attainment }\end{array}$ & & $-0.290^{* * *}$ & & $-0.470^{* * *}$ \\
\hline Poverty & & $-0.216^{*}$ & & $-0.172^{* * *}$ \\
\hline $\mathrm{N}$ & 1698 & 1590 & 1698 & 1590 \\
\hline $\mathrm{R} 2$ & 0.037 & 0.151 & 0.033 & 0.172 \\
\hline
\end{tabular}

Note: ${ }^{* *} \mathrm{p}<0,001 ;{ }^{* *} \mathrm{p}<0,01 ;{ }^{*} \mathrm{p}<0,05 ;+\mathrm{p}<0,10$. Source: Authors' elaboration.

Table 10. Multilevel linear regression models estimating language measures at the end of the first year (wave 2) and the end of the second year (wave 3) of preschool (effect sizes)

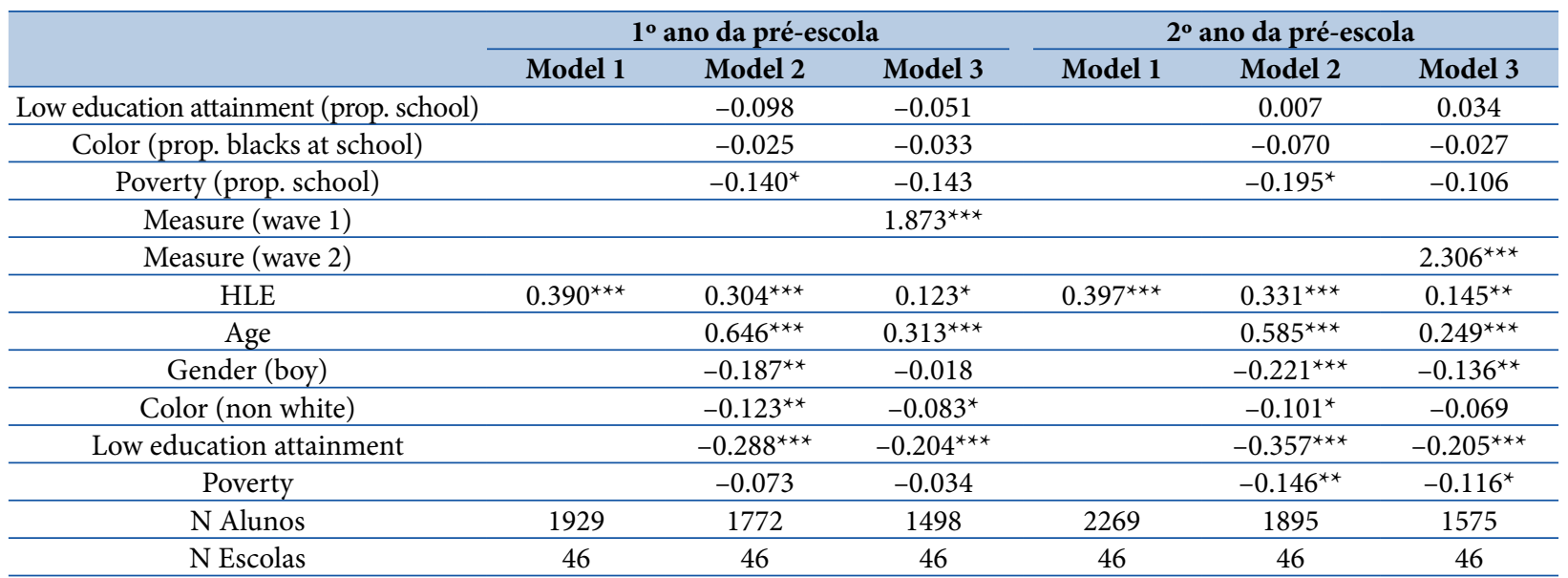

Note: ${ }^{* * *} \mathrm{p}<0,001 ;{ }^{* *} \mathrm{p}<0,01 ;{ }^{*} \mathrm{p}<0,05 ;+\mathrm{p}<0,10$. Source: Authors' elaboration.

Table 11. Multilevel linear regression models estimating math measures at the end of the first year (wave 2) and the end of the second year (wave 3) of preschool (effect sizes)

\begin{tabular}{|c|c|c|c|c|c|c|}
\hline & \multicolumn{3}{|c|}{$1^{\circ}$ ano da pré-escola } & \multicolumn{3}{|c|}{$2^{\circ}$ ano da pré-escola } \\
\hline & Model 1 & Model 2 & Model 3 & Model 1 & Model 2 & Model 3 \\
\hline $\begin{array}{l}\text { Low education attainment } \\
\text { (prop. school) }\end{array}$ & & -0.101 & 0.016 & & -0.052 & 0.002 \\
\hline Color (prop. blacks at school) & & -0.060 & -0.046 & & 0.060 & -0.017 \\
\hline Poverty (prop. school) & & -0.057 & -0.080 & & -0.043 & 0.001 \\
\hline Measure (wave 1) & & & $2.124^{\star * *}$ & & & \\
\hline Measure (wave 2) & & & & & & $2.414^{* * *}$ \\
\hline HLE & $0.414^{* * *}$ & $0.308^{\star \star \star}$ & $0.152^{\star *}$ & $0.373^{\star * \star}$ & $0.324^{\star \star \star}$ & $0.126^{*}$ \\
\hline Age & & $0.064^{\star * *}$ & $0.325^{\star * *}$ & & $0.696^{\star * \star}$ & $0.258^{\star * *}$ \\
\hline Gender (boy) & & -0.064 & 0.049 & & $0.076^{*}$ & $0.191^{\star * *}$ \\
\hline Color (non white) & & $-0.171^{\star \star \star}$ & -0.071 & & $-0.106^{\star}$ & -0.012 \\
\hline Low education attainment & & $-0.372^{\star * *}$ & $-0.172^{\star *}$ & & $-0.313^{* * *}$ & -0.070 \\
\hline Poverty & & $-0.131^{\star}$ & -0.044 & & $-0.152^{\star * *}$ & $-0.102^{*}$ \\
\hline N Alunos & 1929 & 1772 & 1498 & 2269 & 1895 & 1575 \\
\hline N Escolas & 46 & 46 & 46 & 46 & 46 & 46 \\
\hline
\end{tabular}

Note: ${ }^{* *} \mathrm{p}<0,001 ;{ }^{* *} \mathrm{p}<0,01 ;{ }^{*} \mathrm{p}<0,05 ;+\mathrm{p}<0,10$. Source: Authors' elaboration. 